\title{
Planotetraspora silvatica sp. nov. and emended description of the genus Planotetraspora
}

\author{
Tomohiko Tamura and Takeshi Sakane \\ Biological Resource Center, National Institute of Technology and Evaluation, \\ 2-5-8 Kazusakamatari, Kisarazu, Chiba, 292-0812, Japan
}

Correspondence

Tomohiko Tamura

tamura-tomohiko@nite.go.jp
The genus Planotetraspora was proposed by Runmao et al. (1993) to accommodate an actinomycete that was characterized by forming long, cylindrical sporangia containing four spores in a single row at the ends of short sporangiophores on aerial hyphae, having meso-diaminopimelic acid $\left(m e s o-\mathrm{A}_{2} \mathrm{pm}\right)$ in the cell wall and galactose, arabinose, xylose, mannose and ribose in whole-cell hydrolysate. Planotetraspora mira, which was isolated from soil collected in China, was the only known species to belong to the genus Planotetraspora. Kudo (2001) reported that this organism contains madurose and rhamnose, but not arabinose or xylose in its whole-cell hydrolysate, has MK- $9\left(\mathrm{H}_{4}\right)$ as the major isoprenoid quinone and has phospholipid pattern PIV. This genus has been classified in the family Streptosporangiaceae by $16 \mathrm{~S}$ rRNA gene sequence analysis (Stackebrandt et al., 1997; Yokota, 1997).

During a study of the distribution of actinomycetes in the subtropical field, strain TT $00-51^{\mathrm{T}}$ was isolated from soil of Amami Island, Japan. The isolate was judged to belong to the genus Planotetraspora by phylogenetic analysis and chemotaxonomic characteristics, and to represent a novel species of the genus Planotetraspora by DNA-DNA relatedness and physiological characteristics. Therefore, we propose the name Planotetraspora silvatica sp. nov. for strain TT $00-51^{\mathrm{T}}$.

Strain TT $00-51^{\mathrm{T}}\left(=\mathrm{NBRC} 100141^{\mathrm{T}}=\mathrm{DSM} 44746^{\mathrm{T}}\right)$ was isolated from a sample of forest soil in Amami Island,

Abbreviation: $A_{2}$ pm, diaminopimelic acid.

The GenBank/EMBL/DDBJ accession number for the 16S rRNA gene sequence of Planotetraspora silvatica TT $00-51^{\top}$ is $A B 112082$.

A scanning electron micrograph of strain $\mathrm{TT} 00-51^{\top}$ is available as supplementary material in IJSEM Online.
Kagoshima prefecture, Japan. This organism was isolated on humic acid/vitamin (HV) agar (Hayakawa \& Nonomura, 1987) by using the yeast extract/SDS method (Hayakawa \& Nonomura, 1989). Freeze-dried cells for chemotaxonomic analyses were grown in yeast extract/glucose broth $[10 \mathrm{~g}$ yeast extract, $10 \mathrm{~g}$ D-glucose (1 distilled water $)^{-1}, \mathrm{pH} 7 \cdot 0$ ] on a rotary shaker at $28^{\circ}$ C. P. mira NBRC $15435^{\mathrm{T}}$ was also analysed to compare whole-cell sugar patterns.

Cultural and physiological characteristics were determined as described previously (Gordon et al., 1974; Seino et al., 1985; Shirling \& Gottlieb, 1966; Yokota et al., 1993). Morphology was observed by scanning electron microscopy as described previously (Tamura et al., 2000).

Strain TT $00-51^{\mathrm{T}}$ developed sporangia at the ends of short sporangiophores on branched aerial mycelium. Each sporangium was seen to contain four spores. Globose bodies were not observed. Spores were oval to short rods $(0 \cdot 6-0 \cdot 9 \times$ $0 \cdot 8-1 \cdot 5 \mu \mathrm{m})$; motile spores were not observed. A micrograph is available as supplementary material in IJSEM Online.

The strain exhibited good growth on yeast extract/malt extract agar, glycerol/asparagine agar and tyrosine agar, and developed white colonies. In contrast, P. mira NBRC $15435^{\mathrm{T}}$ developed yellow colonies on yeast extract/malt extract agar. The new strain developed white aerial mycelium on yeast extract/malt extract agar, inorganic salts/starch agar, glycerol/asparagine agar, tyrosine agar and HV agar.

The strain utilized mannose, lactose, galactose, methyl $\alpha$-D-glucoside, maltose, rhamnose, melibiose and raffinose. Decomposition of hypoxanthine and L-tyrosine was positive, but resistance to $4 \% \mathrm{NaCl}$, hydrolysis of starch, 
utilization of lactate, malate, succinate, citrate and oxalate and decomposition of urea, adenine, cellulose and calcium malate were negative. The strain showed good growth at $25-30{ }^{\circ} \mathrm{C}$. In contrast, $P$. mira NBRC $15435^{\mathrm{T}}$ did not utilize maltose or galactose or decompose L-tyrosine.

Analyses of whole-cell sugar pattern, cell-wall amino acids, menaquinones, cellular fatty acids, isomers of $\mathrm{A}_{2} \mathrm{pm}$, acyl type of peptidoglycan, mycolic acid and DNA G + C content were performed as described previously (Tamura et al., 1994).

The new strain contained glucose, madurose, galactose, rhamnose and 3-O-methylmannose as whole-cell sugars. In this study, consistent with the results of Kudo (2001), P. mira NBRC $15435^{\mathrm{T}}$ was found to contain madurose and rhamnose, but not xylose or arabinose. The amino acids in the cell wall of the new strain were meso- $\mathrm{A}_{2} \mathrm{pm}$, alanine and glutamic acid; this corresponds to murein type A $\gamma$, according to Schleifer \& Kandler (1972). The predominant isoprenoid quinones of the new strain were MK-9 $\left(\mathrm{H}_{4}\right)$, MK-9 $\left(\mathrm{H}_{2}\right)$ and MK-9. Phosphatidylethanolamine and an unidentified phospholipid containing glucosamine were detected as diagnostic phospholipids, but phosphatidylglycerol and phosphatidylcholine were not detected. The major isoprenoid quinone and phospholipid pattern of strain TT $00-51^{\mathrm{T}}$ were consistent with those of $P$. mira (Kudo, 2001). Mycolic acids were not detected. The glycan moiety of the murein contained acetyl residues. The cellular fatty acids consisted of iso-branched, anteiso-branched, saturated, unsaturated and 10-methylated fatty acids, corresponding to fatty acid pattern 3d of Kroppenstedt (1985). The strain contained diagnostic amounts of 10-methylated $\mathrm{C}_{18: 0}$ and iso- $\mathrm{C}_{16: 0}(>14 \%)$. The DNA G $+\mathrm{C}$ content of the isolate ranged from 70 to $71 \mathrm{~mol} \%$.

The microplate hybridization method developed by Ezaki et al. $(1988,1989)$ was applied with minor modifications to determine DNA-DNA relatedness (Tamura et al., 1999).
The strain exhibited DNA-DNA relatedness levels of $38-42 \%$ with P. mira NBRC $15435^{\mathrm{T}}$.

PCR amplification and sequencing of the 16S rRNA gene were performed as described previously (Tamura \& Hatano, 2001) with a model ABI PRISM 3100 genetic analyser (Applied Biosystems) according to the manufacturer's protocol. Phylogenetic analysis of 16S rRNA gene sequences was performed as described previously (Tamura \& Hatano, 2001). This phylogenetic analysis revealed that the isolate fell within the cluster of the family Streptosporangiaceae and, with $P$. mira NBRC $15435^{\mathrm{T}}$, formed a line of descent that was distinct from other actinomycetes of this family (Fig. 1). The signature nucleotides of the 16S rRNA gene at positions 502-543 (A-U) and 1116-1184 (U-G) of P. mira NBRC $15435^{\mathrm{T}}$ and the isolate were different from those of other members of the family Streptosporangiaceae [positions 502-543 (G-C), 1116-1184 (C-G)]. The closest neighbours are members of the genera Acrocarpospora (similarity values $95 \cdot 8-97 \cdot 1 \%$ ) and Herbidospora (similarity values $95 \cdot 8-97 \cdot 1 \%)$.

Strain TT $00-51^{\mathrm{T}}$ developed cylindrical sporangia at the ends of short sporangiophores on aerial hyphae, with each sporangium containing four spores in a single row. These morphological characteristics are consistent with those of the genus Planotetraspora. The genus Planotetraspora resembles the genus Microtetraspora in this characteristic (Kudo, 2001), but the two genera can be distinguished by their $16 \mathrm{~S}$ rRNA gene sequences. Strain TT $00-51^{\mathrm{T}}$ formed a monophyletic cluster with $P$. mira NBRC $15435^{\mathrm{T}}$. Strain TT $00-51^{\mathrm{T}}$ and $P$. mira are the phylogenetically closest neighbours of the genera Herbidospora (Kudo et al., 1993) and Acrocarpospora (Tamura et al., 2000). Members of the genus Herbidospora develop short chains of non-motile spores (10-30 spores per chain) that are borne on the tips of sporophores arising directly from the agar surface. Members of the genus Acrocarpospora develop a few club-shaped and many spherical sporangia that are borne on the tips of aerial

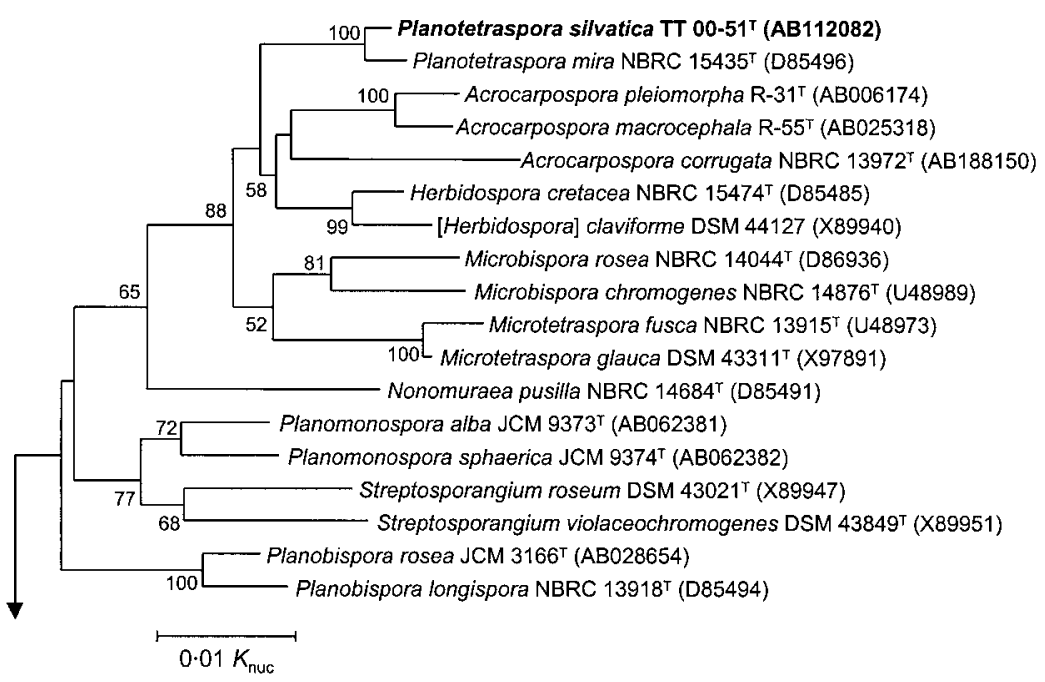

Fig. 1. Phylogenetic tree based on neighbourjoining (Saitou \& Nei, 1987), derived from 16S rRNA gene sequences for members of the family Streptosporangiaceae. Streptomyces ambofaciens ATCC 23877 ${ }^{\top}$ (GenBank accession no. M27245) was used as the root. Numbers on branches are confidence limits (expressed as percentages) estimated from a bootstrap analysis with 1000 replicates (only percentages above 50\% are indicated). Bar, $0.01 K_{\text {nuc }}$. 
hyphae. Members of the genus Planotetraspora can be distinguished from these two genera on the basis of morphological criteria, although the three genera show high $16 \mathrm{~S}$ rRNA gene sequence similarity.

On the basis of morphological, chemotaxonomic and phylogenetic criteria, strain TT $00-51^{\mathrm{T}}$ is considered to belong to the genus Planotetraspora and to represent a distinct species, based on DNA-DNA relatedness and physiological characteristics (Table 1). We propose that the isolate should be classified as the type strain of a novel species, Planotetraspora silvatica sp. nov. (type strain, TT $00-51^{\mathrm{T}}$ $=$ NBRC $100141^{\mathrm{T}}=\operatorname{DSM} 44746^{\mathrm{T}}$ ).

\section{Emended description of the genus Planotetraspora Runmao et al. 1993}

The description is based on data taken from earlier studies (Runmao et al., 1993; Kudo, 2001) and our own studies. Cells are Gram-positive, non-acid-fast and aerobic, with branching hyphae. Non-fragmentary substrate mycelia are present. Long, cylindrical sporangia are formed at the ends of short sporangiophores on aerial hyphae, with each sporangium containing four spores in a single row. Spores are short cylindrical, short rod or oval in shape $(0 \cdot 4-1 \cdot 4 \times 0 \cdot 8-1 \cdot 5 \mu \mathrm{m})$ and may exhibit motility. Good growth occurs between 25 and $30{ }^{\circ} \mathrm{C}$. In general, vegetative mycelia are pale yellow to white. Cell walls contain glutamic acid, alanine and meso- $\mathrm{A}_{2} \mathrm{pm}$. Wall chemotype is III, according to Lechevalier \& Lechevalier (1970), and the peptidoglycan type is presumed to be $\mathrm{A} 1 \gamma$, according to Schleifer \& Kandler (1972). Madurose, 3-O-methylmannose, rhamnose, glucose and galactose are detected as whole-cell sugars. Major cellular fatty acid is 10-methylated $\mathrm{C}_{18: 0}$. Major menaquinone is $\mathrm{MK}-9\left(\mathrm{H}_{4}\right)$. Phosphatidylethanolamine is present as the diagnostic phospholipid [phospholipid pattern type PIV, according to Lechevalier et al. (1977)]. Acyl type of cell-wall polysaccharides is acetyl. Mycolic acid is not detected. DNA G $+\mathrm{C}$ content is $71 \mathrm{~mol} \%$. Habitat is soil. The type species is Planotetraspora mira.

\section{Description of Planotetraspora silvatica sp. nov.}

Planotetraspora silvatica (sil.va'ti.ca. L. fem. adj. silvatica of the forest).

Morphological, chemotaxonomic and general characteristics are as given above for the genus. Brownish, soluble pigment is produced on tyrosine agar (ISP medium 7). Starch is not hydrolysed. Hydrolysis of gelatin is negative or weakly positive. Calcium malate is not decomposed.

Table 1. Diagnostic characteristics that differentiate $P$. silvatica TT $00-51^{\top}$ from $P$. mira NBRC $15435^{\top}$

Species: 1 , P. silvatica TT $00-51^{\mathrm{T}} ; 2$, P. mira NBRC $15435^{\mathrm{T}}$.

\begin{tabular}{|c|c|c|}
\hline Characteristic & 1 & 2 \\
\hline \multicolumn{3}{|l|}{ Cultural characteristics } \\
\hline \multicolumn{3}{|l|}{ ISP medium no. 2 : } \\
\hline Growth & Good, white to colourless & Good, pale yellow $(45)^{\star}$ \\
\hline Aerial mycelium or spore & Good, white & Moderate, white \\
\hline Reverse colour & White to colourless & Pale yellow (45) \\
\hline \multicolumn{3}{|l|}{ ISP medium no. $4:$} \\
\hline Growth & Good, white to colourless & Poor, colourless \\
\hline \multicolumn{3}{|l|}{ Physiological characteristics } \\
\hline \multicolumn{3}{|l|}{ Acid from: } \\
\hline Mannose & - & + \\
\hline Lactose & - & + \\
\hline Mannitol & - & + \\
\hline Rhamnose & - & + \\
\hline \multicolumn{3}{|l|}{ Utilization of: } \\
\hline Glucose & - & + \\
\hline Xylose & - & + \\
\hline Galactose & ++ & \pm \\
\hline Raffinose & + & - \\
\hline Mannitol & - & + \\
\hline Maltose & ++ & \pm \\
\hline Melibiose & + & - \\
\hline Decomposition of xanthine & + & - \\
\hline
\end{tabular}

*The code of colours corresponds to the mycological colour chart of Rayner (1970). 
Coagulation and peptonization of milk are positive. Optimum temperature for growth is $25-30^{\circ} \mathrm{C}$. Does not grow at $37^{\circ} \mathrm{C}$. Does not grow on $4 \% \mathrm{NaCl}$. Glucose, mannose, lactose, galactose, methyl $\alpha$-D-glucoside, maltose, rhamnose and melibiose are utilized, but dulcitol, erythritol, adonitol and arabinose are not. As major cellular fatty acids, 10-methylated $\mathrm{C}_{18: 0}$ and iso- $\mathrm{C}_{16: 0}$ are present. DNA $\mathrm{G}+\mathrm{C}$ content is $71 \mathrm{~mol} \%$.

The type strain is TT $00-51^{\mathrm{T}}\left(=\mathrm{NBRC} 100141^{\mathrm{T}}=\mathrm{DSM}\right.$ $\left.44746^{\mathrm{T}}\right)$. Habitat is soil.

\section{Acknowledgements}

This work was supported by Grant-in-Aid for Scientific Research (C) (2) no. 11660326 from the Japan Society for the Promotion of Science. The authors are grateful to Drs A. Nakagiri, Y. Nakagawa, I. Okane and K. Ueda-Nishimura for kind help.

\section{References}

Ezaki, T., Hashimoto, Y., Takeuchi, N., Yamamoto, H., Liu, S.-L., Miura, H., Matsui, K. \& Yabuuchi, E. (1988). Simple genetic method to identify viridans group streptococci by colorimetric dot hybridization and quantitative fluorometric hybridization in microdilution wells. J Clin Microbiol 26, 1708-1713.

Ezaki, T., Hashimoto, Y. \& Yabuuchi, E. (1989). Fluorometric deoxyribonucleic acid-deoxyribonucleic acid hybridization in microdilution wells as an alternative to membrane filter hybridization in which radioisotopes are used to determine genetic relatedness among bacterial strains. Int J Syst Bacteriol 39, 224-229.

Gordon, R. E., Barnett, D. A., Handerhan, J. E. \& Pang, C. H.-N. (1974). Nocardia coeliaca, Nocardia autotrophica, and the nocardin strain. Int J Syst Bacteriol 24, 54-63.

Hayakawa, M. \& Nonomura, H. (1987). Humic acid-vitamin agar, a new medium for the selective isolation of soil actinomycetes. J Ferment Technol 65, 501-509.

Hayakawa, M. \& Nonomura, H. (1989). A new method for the intensive isolation of actinomycetes from soil. Actinomycetologica 3, 95-104.

Kroppenstedt, R. M. (1985). Fatty acid and menaquinone analysis of actinomycetes and related organisms. In Chemical Methods in Bacterial Systematics, pp. 173-199. Edited by M. Goodfellow \& D. E. Minnikin. London: Academic Press.

Kudo, T. (2001). Family Streptosporangiaceae. In Identification Manual of Actinomycetes, pp. 259-276. Edited by S. Miyadoh, M. Hamada, K. Hotta, T. Kudo, A. Seino, K. Suzuki \& A. Yokota. Tokyo, Japan: Business Center for Academic Societies.

Kudo, T., Itoh, T., Miyadoh, S., Shomura, T. \& Seino, A. (1993). Herbidospora gen. nov., a new genus of the family
Streptosporangiaceae Goodfellow et al. 1990. Int J Syst Bacteriol 43, 319-328.

Lechevalier, M. P. \& Lechevalier, H. (1970). Chemical composition as a criterion in the classification of aerobic actinomycetes. Int J Syst Bacteriol 20, 435-443.

Lechevalier, M. P., De Bievre, C. \& Lechevalier, H. (1977). Chemotaxonomy of aerobic actinomycetes: phospholipid composition. Biochem Syst Ecol 5, 249-260.

Rayner, R. W. (1970). A Mycological Colour Chart. Kew, UK: Commonwealth Mycological Institute and British Mycological Society.

Runmao, H., Guizhen, W. \& Junying, L. (1993). A new genus of actinomycetes, Planotetraspora gen. nov. Int J Syst Bacteriol 43, $468-470$.

Saitou, N. \& Nei, M. (1987). The neighbor-joining method: a new method for reconstructing phylogenetic trees. Mol Biol Evol 4, 406-425.

Schleifer, K. H. \& Kandler, O. (1972). Peptidoglycan types of bacterial cell walls and their taxonomic implications. Bacteriol Rev 36, 407-477.

Seino, A., Arai, M., Enokida, R., Okazaki, T. \& Furuichi, A. (1985). Identification Manual of Actinomycetes. Tokyo, Japan: Society for Actinomycetes.

Shirling, E. B. \& Gottlieb, D. (1966). Methods for characterization of Streptomyces species. Int J Syst Bacteriol 16, 313-340.

Stackebrandt, E., Rainey, F. A. \& Ward-Rainey, N. L. (1997). Proposal for a new hierarchic classification system, Actinobacteria classis nov. Int J Syst Bacteriol 47, 479-491.

Tamura, T. \& Hatano, K. (2001). Phylogenetic analysis of the genus Actinoplanes and transfer of Actinoplanes minutisporangius Ruan et al. 1986 and 'Actinoplanes aurantiacus' to Cryptosporangium minutisporangium comb. nov. and Cryptosporangium aurantiacum sp. nov. Int J Syst Evol Microbiol 51, 2119-2125.

Tamura, T., Nakagaito, Y., Nishii, T., Hasegawa, T., Stackebrandt, E. \& Yokota, A. (1994). A new genus of the order Actinomycetales, Couchioplanes gen. nov., with descriptions of Couchioplanes caeruleus (Horan and Brodsky 1986) comb. nov. and Couchioplanes caeruleus subsp. azureus subsp. nov. Int J Syst Bacteriol 44, 193-203.

Tamura, T., Hayakawa, M. \& Hatano, K. (1999). Sporichthya brevicatena sp. nov. Int J Syst Bacteriol 49, 1779-1784.

Tamura, T., Suzuki, S. \& Hatano, K. (2000). Acrocarpospora gen. nov., a new genus of the order Actinomycetales. Int J Syst Evol Microbiol 50, 1163-1171.

Yokota, A. (1997). Phylogenetic relationship of actinomycetes. In Atlas of Actinomycetes, pp. 194-197. Edited by M. Hamada, K. Hotta, T. Kudo, S. Miyadoh, A. Seino, K. Suzuki \& A. Yokota. Tokyo: Asakura Publishing Company.

Yokota, A., Tamura, T., Hasegawa, T. \& Huang, L. H. (1993). Catenuloplanes japonicus gen. nov., sp. nov., nom. rev., a new genus of the order Actinomycetales. Int J Syst Bacteriol 43, 805-812. 